\title{
Over-Expression of CXCR4, a Stemness Enhancer, in Human Blastocysts by Low Level Laser Irradiation
}

\author{
Mohammad Hossein Tahmasbi ${ }^{1}$, Mohammad Shafiee ${ }^{2}$, Mohammad Taghi Joghataei ${ }^{1}$, Seyed Amir Yazdanparast ${ }^{1}$, Seyed AkbarMoosavi \\ ${ }^{3}$, Mina Jafarabadi ${ }^{4 *}$, Masoud Soleimani ${ }^{5}$ \\ ${ }^{1}$ Cellular and Molecular Research Centre, Tehran University of Medical sciences (TUMS), Tehran, Iran. \\ ${ }^{2}$ Omics Research Center, Golestan University of Medical Sciences, Gorgan, Iran. \\ ${ }^{3}$ Department of Allied Health, Tehran University of Medical Sciences (TUMS), Tehran, Iran. \\ ${ }^{4}$ Reproductive Health Research Center, Tehran University of Medical Sciences (TUMS), Tehran, Iran. \\ ${ }^{5}$ Department of Hematology, Faculty of Medical Sciences, Tarbiat Modares University, Tehran, Iran.
}

\section{Received: 15 Apr 2013}

Revised : 27 Jun 2013

Accepted: 21 Sep 2013

Corresponding Authors:

Mina Jafarabadi

Reproductive Health Research Center,

Tehran University of Medical

Sciences (TUMS), Tehran, Iran

E-mail: Jafarabadi@tums.ac.ir

\begin{abstract}
Background: The key role of chemokine receptor CXCR4 in the maintenance of stemness property of stem cells has been shown recently. The low level laser irradiation (LLLI) is being used currently in a wide variety of clinical cases as a therapeutic tool for wound healing, relieving pain and destroying tumor cells. The aim of this study was to evaluate the effect of LLLI mimicking low level laser therapy (LLLT) on the expression level of CXCR4 gene a few hours after irradiation on human blastocysts.

Materials and Methods: After the development of human embryos to the first grade blastocyst stage, they were irradiated with a low power Ga-Al-As laser at a continuous wavelength of $650 \mathrm{~nm}$ and a power output of $30 \mathrm{~mW}$. Total RNA of the irradiated blastocysts and control groups was isolated in groups of $1 \times 2 \mathrm{~J} / \mathrm{cm}^{2}$, $2 \times 2 \mathrm{~J} / \mathrm{cm}^{2}, 1 \times 4 \mathrm{~J} / \mathrm{cm}^{2}$ and $2 \times 4 \mathrm{~J} / \mathrm{cm}^{2}$ LLLI. Specific real-time PCR primers were designed to amplify all the two CXCR4 isoforms yet identified. RNA amplifications were done for all groups.

Results: We showed for the first time that LLLI makes the human blastocysts to increase the expression level of CXCR4 a few hours after irradiation. Moreover, it was shown that two irradiation doses with one day interval can cause a significant increase in CXCR4 expression level in human blastocysts.

Conclusion: This study revealed that LLLI could be a proliferation motivator for embryonic cell divisions through enhanced over-expression of CXCR4 level.
\end{abstract}

Keywords: CXCR4; Human blastocysts; Low-level laser irradiation (LLLI); Proliferation; Stemness

Please cite this article as: Tahmasbi MH, Shafiee M, Joghataei MT, Yazdanparast SA, Moosavi SA, Jafarabadi M, Soleimani M. Over-Expression of CXCR4, a Stemness Enhancer, in Human Blastocysts by Low Level Laser Irradiation. Res Mol Med. 2013; 1 (2): 17-22

\section{Introduction}

Low level laser therapy (LLLT) refers to the use of red-beam or near-infrared lasers with a wavelength of $600-1100 \mathrm{~nm}$ and an output power of $1-500 \mathrm{~mW}$. This type of radiation is a continuous wave or pulsed light that consists of a constant beam of relatively low energy density $\left(0.04-50 \mathrm{~J} / \mathrm{cm}^{2}\right)$, and the laser is directed at the target tissue or monolayer of cells using powers measured in milliwatt $(\mathrm{mW})$. Low level low-levels of red/near-infrared light illumination (1-
2). At low doses $\left(2 \mathrm{~J} / \mathrm{cm}^{2}\right)$, the LLLI stimulates proliferation, while at high doses $\left(16 \mathrm{~J} / \mathrm{cm}^{2}\right)$ LLLI is suppressive, pointing to the dose dependence of biological responses after light exposure (3). However, stimulation in cell proliferationhas been shown to occur outside these ranges (4). A number of different laser light sources, including helium-neon, ruby and gallium- aluminum-arsenide, have been used to deliver LLLI in different treatments and on 
different schedules. LLLI transmits energy at low levels and therefore does not emit heat, sound or vibrations. Its reactions are non-thermal because there is no immediate increase in the temperature of the laser-irradiated tissue. Experiments following LLLI exposure have shown that the immediate increase in heat of the target tissue is negligible $\left( \pm{ }^{\circ} \mathrm{C}\right)(5)$. It has been confirmed by many investigators that the temperature remained unchanged in fibroblast suspensions during LLLI irradiation (6). As well as reported announced that a temperature increase of less than $0.065^{\circ} \mathrm{C}$, with laser irradiation of 40 $\mathrm{mW} / \mathrm{cm}^{2}$, using a microthermo probe in a monolayer of cells. In contrast, high-energy lasers (e.g., carbon dioxide lasers and neodymium-YAG lasers) are able to raise the tissue temperature high enough to cut and vaporize them (7).

\section{Applications of LLLI in regenerative medicine}

The LLLT has been used for wound healing since a few decades ago. It is also widely applied in different branches of regenerative medicine (e.g., tissue regeneration) (8) and dentistry, where it is used to enhance the healing process (9). Earlier, the LLLI was shown to have beneficial effects on variety of pathological and clinical conditions including pain relief and inflammatory condition (10). Recently, it has been reported that LLLI could also enhance the proliferation of mesenchymal and cardiac stem cells (11), and differentiation of human embryonic stem cells (12).

\section{Cell signaling after LLLI}

Cell proliferation is a very important physiological effect of LLLI. The LLLI is used in basic experimental cell culture procedures and clinical practice (13). Nonetheless it promotes the proliferation of multiple cells, mainly through the activation of mitochondrial respiratory chain and the initiation of cellular signaling. The alterations in photoacceptor function are the primary reactions, and the subsequent alterations in cellular signaling and cellular functions are secondary reactions (14). The primary reactions after light absorption are singletoxygen hypothesis, redox properties alteration hypothesis, nitric oxide hypothesis, transient local heating hypothesis and superoxide anion hypothesis (15). The secondary reactions after light absorption are cellular signaling pathways, including the mitochondrial retrograde signaling (16).

\section{CXCR4 as an involved gene in stemness}

A superfamily of chemoattracting molecules called chemokines are cytokine-like proteins that bind to and activate a family of chemokine receptors. More than 50 chemokines have been identified, and they are divided into 4 families on the basis of the positions of 4 conserved cysteine residues: CXC, CX3C, CC and C (17). Chemokine receptors are seven-transmemberane receptors coupled to Gproteins, with their C-terminus in the cytoplasm, three extracellular and three intracellular loops as well as an $\mathrm{N}$-terminus outside the cell surface. One of the intracellular loops of the chemokine receptors couples with heterotrimeric G-proteins and that mediate ligand binding to the receptor which initiates a cascade of signal transduction events (18).

There is a high degree of redundancy in the chemokine family as multiple chemokines bind to the same receptor (19).

Yet chemokines and their receptors have been identified to have important roles in inflammation, infection, tissue injury, allergy, cardiovascular diseases and malignant tumors (20). Regulating metastasis is one of the most important roles of chemokines and the chemokine receptors. Chemokine receptors may potentially facilitate tumor dissemination at each of the key steps of metastasis, including adherence of tumor cells to endothelium, extravasation from blood vessels, metastatic colonization, angiogenesis, proliferation and protection from the host response via activation of key survival pathways such as ERK/MAPK, PI-3K/Akt/mTOR or Jak/STAT (21). Of the chemokine receptors the CXCR4 is a highly conserved G-protein which couples sevenspan transmembrane receptors (GPCR) that binds the ligands such as CXCL12 $\alpha$ and CXCR4. It has received considerable attention since it serves as a coreceptor for entry of T-tropic (X4) HIV viruses that target $\mathrm{CD}^{+} \mathrm{T}$ cells $(22)$. The CXCR4 is expressed in different cell types (e.g. central nervous systems and immune systems) during the development. It can also mediate migration of resting leukocytes and hematopoietic progenitors in response to CXCL12 functioning in a number of physiological processes (23). In the marrow and regulating stem cell trafficking, differential expression of CXCR4 in $\mathrm{CD}_{3} 4^{+}$progenitor cells may be involved in maintaining hematopoietic progenitor cells (24). For example, the deficiency of CXCL12/CXCR4 axis leads to circulatory, CNS, immune and hematopoietic defects. This axis plays an important role in the embryonic development (25). CXCR4 is over-expressed in more than 23 human cancers, including breast, ovarian, melanoma and prostate cancers (26). Although CXCR4 is expressed in a broad array of tissues, its expression is low or absent in many normal tissues, including breast and ovary (27). Vascular endothlial growth factor (VEGF) is a known inducer of CXCR4 expression and it has been shown that Hypoxy Inhibiting Factor-1 (HIF-1) acts as an upstream to induce VEGF and the heterodimeric 
transcription factor responsive to oxygen concentrations in tissues. It can also up-regulate CXCR4 expression. CXCR4 is functionally crucial for maintenance of stemness in drug-resistant non-small cell lung cancer cells (28).

\section{Materials and Methods \\ Human embryos and ethical approval}

Human embryos used for the present study were donated (the consent was given) from couples who underwent in vitro fertilization (IVF) program for infertility treatment at reproduction medicine unit, Department of Obstetrics and Gynecology, Shariati Hospital, Tehran University of Medical Sciences (TUMS) in accordance with medical research ethical regulations of the Ministry of Health and Medical Education of Iran.

\section{Culture of human embryos}

Fresh normal and frozen-thawed normal fertilization at pronuclear (PN)- stage embryos were transferred to droplets of global $\AA$ medium (Life Global) supplemented with 10\% Serum Substitute Supplement (SSSTM) (Irvine Scientific), covered with light oil (Life Global), and cultured at $37{ }^{\circ} \mathrm{C}, 5 \% \mathrm{O}_{2} 60 \%$ $\mathrm{CO}_{2}, 89 \% \mathrm{NO}_{2}$. The resulted blastocysts were then prepared for $72 \mathrm{~h}$ for low level laser treatment.

\section{Irradiation on human blastocysts via laser}

The blastocysts were irradiated with a low power GaAl-As laser (Metron Inc., Australia) at a continuous wavelength of $650 \mathrm{~nm}$ and a power output of $30 \mathrm{~mW}$ based on grading system reported by Gardner (93). Blastocysts were irradiated at a distance of $15 \mathrm{~mm}$ from the laser probe tip. The beam diameter of the laser was $6 \mathrm{~mm}$.

The provided blastocysts were divided into two groups. The first and the second groups were irradiated for $30 \mathrm{~s}\left(2 \mathrm{~J} / \mathrm{cm}^{2}\right)$ and $30 \mathrm{~s}\left(4 \mathrm{~J} / \mathrm{cm}^{2}\right)$, respectively. Furthermore, each group was divided into two subgroups, one with no irradiation and the other treated with irradiation for the second time, a day after the first irradiation treatment and with the identical laser wavelength $\left(2 \times 2 \mathrm{~J} / \mathrm{cm}^{2}\right.$ and $\left.2 \times 4 \mathrm{~J} / \mathrm{cm}^{2}\right)$. Each group consisted of five wells. Blastocysts in 96well plates were seeded in wells far from each other to avoid overlapping or scattered irradiation. The cover of the plate was off during the irradiation period and treatment was done at room temperature. Control blastocysts were subjected to the same procedure as the irradiated cells but the laser was not turned on. In order to avoid influence of second-order variables, the blastocysts of two experimental groups, including the control group (non-irradiated), were exposed to the same environmental and stress conditions such as temperature, humidity and light.
Regarding the light, during the experiment, all dishes were covered by black box to prevent light exposure. Identical samples from each group were taken for random cell counting 2, 4 and 6 days after the first irradiation. Then we compared the effect of laser with different power outputs on cell proliferation.

\section{Culture of human blastocysts}

To culture the isolated blastocysts, the culture medium was changed to human embryonic stem cell culture medium, consisting of knockout ${ }^{\mathrm{TM}}$ DMEM (Invitrogen) supplemented with $20 \%$ knock out serum replacement, $1 \%$ glutamax $^{\mathrm{TM}}, 0.5 \mathrm{mM} \beta$ mercaptoethanol, $50 \mathrm{U} / \mathrm{ml}$ penicillin, $50 \mu \mathrm{g} / \mathrm{ml}$ streptomycin (Invitrogen), 1\% nonessential amino acids and $8 \mathrm{ng} / \mathrm{ml} \mathrm{bFGF} \mathrm{(Invitrogen).} \mathrm{Blastocysts}$ were cultured 7 days until the inner cell mass (ICM) outgrowths were formed.

\section{Proliferation assay}

Blastocysts proliferation of all eight cell groups (irradiated and controls), was evaluated on the $4^{\text {th }}$ day after the first irradiation, by 3- (4, 5-Dimethylthiazol2-yl) -2, 5-diphenyltetrazoliummbromide (MTT) assay. In order to determine cell numbers, the culture medium was removed and $100 \mu \mathrm{l}$ of fresh culture medium containing $50 \mu \mathrm{l}$ of MTT $(5 \mathrm{mg} / \mathrm{ml}$, Sigma) was added to each well. The cells were then incubated at $37{ }^{\circ} \mathrm{C}$ for $4 \mathrm{~h}$. The color was extracted with $100 \mu \mathrm{l} \mathrm{DMSO}$ at $37{ }^{\circ} \mathrm{C}$ for $6 \mathrm{~m}$. $\mathrm{OD}_{490}$, which was directly related to the viable cell numbers, was determined at room temperature and cell growth curves were plotted.

RNA isolation and cDNA synthesis

Total RNA was isolated from all eight cell groups (groups irradiated at $1 \times 2 \mathrm{~J} / \mathrm{cm}^{2}, 2 \times 2 \mathrm{~J} / \mathrm{cm}^{2}, 1 \times 4 \mathrm{~J} / \mathrm{cm}^{2}$, $2 \times 4 \mathrm{~J} / \mathrm{cm}^{2}$ LLLI, and their controls) using Trizol Reagent (Invitrogen) according to the manufacturer's instructions, and dissolved in RNase-free water. The quality and quantity of the extracted RNAs were measured by gel electrophoresis and spectrophotometry, respectively. To remove the whole DNA contamination, equal amounts of RNA were treated with RNase-free DNase (Takara, Japan) and then the first strand of cDNA synthesized by reverse transcriptase (Takara, Japan), using both oligo dT and random hexamer primers (Takara, Japan) according to the manufacturer's instructions. For each sample, a no-reverse transcription control was used in parallel to the DNase-treated RNA to detect non-specific amplification of genomic DNA.

Reverse transcription quantitative real-time PCR Specific real-time PCR primers (MWG Biotech, Germany) were designed using GenRunner software 
to amplify all two CXCR4 isoforms ((isoform a (accession No, NM_001008540.1) and isoform b (accession No, NM_003467.2)). We used glyceraldehyde 3-phosphate dehydrogenase (GAPDH) (accession No, NM_002046.4) as a reference gene or internal control in our measurement. PCR reaction was performed using $3 \mu \mathrm{l}$ of cDNA or no-reverse transcription sample with $10 \mu \mathrm{l}$ SYBR Premix Ex Taq II master mix (TaKaRa) U of Taq and $0.5 \mu \mathrm{M}$ of each primer in a $25 \mu \mathrm{l}$ PCR reaction. Real-time PCR reaction supplemented with ROX reference Dye II was used for all amplification reactions. The amplification carried out using the following cycling conditions: initiation at $95{ }^{\circ} \mathrm{C}$ for $5 \mathrm{~m}$, amplification for 40 cycles with denaturation at $94{ }^{\circ} \mathrm{C}$ for $15 \mathrm{~s}$, annealing at $58^{\circ} \mathrm{C}$ for $30 \mathrm{~s}$ and extending at $72^{\circ} \mathrm{C}$ for $15 \mathrm{~s}$ and final extension at $72{ }^{\circ} \mathrm{C}$ for $10 \mathrm{~m}$. All realtime PCR reactions were carried out by the ABI 7500 Real-Time PCR systems (Applied Biosystems, FosterCity, CA).

Table 1. Primers designed for CXCR4 and GAPDH

\begin{tabular}{llll}
\hline Gene name & F/R & Primer & $\begin{array}{l}\text { Product } \\
\text { (bp) }\end{array}$ \\
\hline CXCR4 & F & $\begin{array}{l}\text { GGTCCATGGTTACCA } \\
\text { GAAGA }\end{array}$ & \\
& R & $\begin{array}{l}\text { GTCATCTGCCTCACT } \\
\text { GACGTTG }\end{array}$ & 364 \\
& F & $\begin{array}{l}\text { GCCACATCGCTCAG } \\
\text { ACAC }\end{array}$ & \\
GAPDH & $\mathrm{R}$ & $\begin{array}{l}\text { GGAACAATATCCA } \\
\text { CTTACCAG }\end{array}$ & 115 \\
\hline
\end{tabular}

Forcompensatig variations in the amount of input RNA and the efficacy of reverse transcriptase, GAPDH mRNA was also quantified as internal control, and the expression data were normalized to GAPDH expression value in each sample. PCR products were separated on a $1 \%$ agarose gel, stained with ethidium bromide and visualized under the UV light. Direct DNA sequencing (MWG, Germany) confirmed the PCR products.

\section{Statistical analysis}

Data are presented with mean \pm SD of three independent experiments $(n=3$ for each individual group and assay). The data were compared by ANOVA test followed by the Tukey test. The level of significance was 5\% $(\mathrm{p}<0.05)$.

\section{Results}

Effect of LLLI on the proliferation of human blastocysts

Proliferation of human blastocysts was detected in all eight cell groups (groups in which human blastocysts were irradiated at $1 \times 2 \mathrm{~J} / \mathrm{cm}^{2}, 2 \times 2 \mathrm{~J} / \mathrm{cm}^{2}, 1 \times 4 \mathrm{~J} / \mathrm{cm}^{2}$ and $2 \times 4 \mathrm{~J} / \mathrm{cm}^{2}$ LLLI. The number of viable human blastocysts, expressed as $\mathrm{OD}_{490}$, was detected by the MTT assay on the $3^{\text {rd }}$ day of the first irradiation by related medium. The $\mathrm{OD}_{490}$ in groups irradiated at $2 \times 2 \mathrm{~J} / \mathrm{cm}^{2}$ and $2 \times 4 \mathrm{~J} / \mathrm{cm}^{2}$ was significantly higher than that in the non-irradiated groups $(\mathrm{p}<0.01)$. Also $\mathrm{OD}_{490}$ in groups irradiated at $2 \times 4 \mathrm{~J} / \mathrm{cm}^{2}$ and $2 \times 2 \mathrm{~J} / \mathrm{cm}^{2}$ was significantly higher than that one irradiated at $1 \times 4 \mathrm{~J} / \mathrm{cm}^{2}$ and $1 \times 2 \mathrm{~J} / \mathrm{cm}^{2}$, respectively $(\mathrm{p}<0.01)$.

The effect of LLLI on human blastocysts after irradiation

RNA was extracted using Trizol Reagent (Invitrogen), according to the manufacturer's instructions, from two biological replicates $12 \mathrm{~h}$ after irradiation. CXCR4 expression levels were determined from RNA isolated at 0 and $12 \mathrm{~h}$ after the treatment and quantified relative to GAPDH expression level. The control time point $(\mathrm{t}=0)$ expression level was set to $100 \%$ and treated samples were shown as a percentage of the control (Fig. 1)

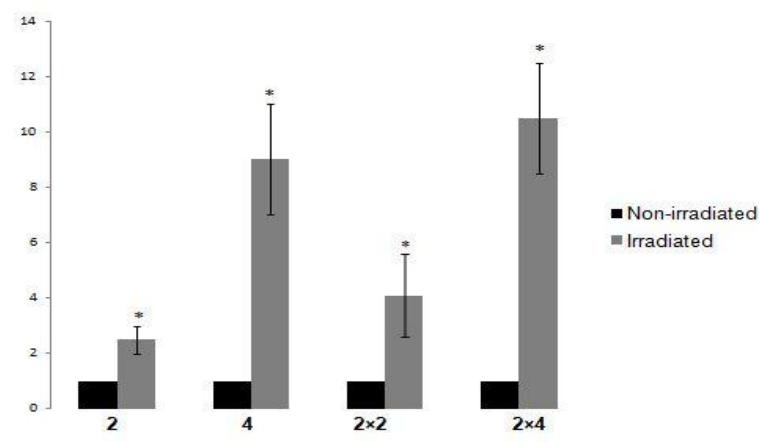

Figure 1. The effect of different doses of low level laser irradiation on human blastocysts, as the expression level of CXCR4 transcript was analyzed by real-time quantitative RT-PCR in human blastocysts after $2 \mathrm{~J} / \mathrm{cm}^{2}$ and $2 \times 2 \mathrm{~J} / \mathrm{cm}^{2}$ (two times irradiation each time with $2 \mathrm{~J} / \mathrm{cm}^{2}$ ), $4 \mathrm{~J} / \mathrm{cm}^{2}$ and $2 \times 4 \mathrm{~J} / \mathrm{cm}^{2}$ (two times irradiation each time with $4 \mathrm{~J} / \mathrm{cm}^{2}$ ) LLLI in comparison with their paired non-irradiated $(* \mathrm{P}$-value $<0.05$ )

\section{Discussion}

We showed for the first time that low power laser irradiation makes the human blastocysts to increase the expression level of CXCR4 a few hours after irradiation. Moreover, we demonstrated that two irradiations with one day interval cause a significant increase in CXCR4 expression level in human blastocysts.

This finding is important in regenerative medicine and reproductive technologies. Self-renewal, which is considered as the ability of stem cells to be divided and reproduced, discriminates these cells from the other cells. As we mentioned earlier, the key role of the chemokine receptor CXCR4 in the maintenance of stemness property of stem cells has been observed 
and published recently (20). Blastocysts are pleuripotent stem cells (12). Some genes are common stemness regulators, such as SOX2, OCT4, Nanog, KLF4; however, the role of CXCR4 has not been shown clearly. This finding is the first report of CXCR4 in human blastosyst irradiated with laser. Thus, LLLI could be a candidate tool for nondividing freeze-thawed in vitro fertilization (IVF) embryos through over-expression of CXCR4. In regard to possible molecular mechanism, the possibility of binding of CXCR4 to more than one ligand, as occurs for many chemokine receptors, may lead to identification of novel ligands or characterization of different expression levels of its common cognate receptors such as CXCL12 in blastocysts. LLLI may trigger an intracellular cascade signaling pathway through which a conformational change in molecules involved in cell proliferation and self-renewal of blastocysts may occur or may activate or inactivate enzymes that catalyze cell proliferation, which requires further studies to be cleared.

\section{Conclusions}

LLLI may be a candidate tool for motivation of nondividing freeze-thawed in vitro fertilization (IVF) embryos through over-expression of CXCR4 as we showed in this study for the first time.

\section{Acknowledgements}

The authors wish to thank Dr. Seyed Hojattollah Saeidi and Alireza Shahryari for their assistance.

\section{References}

1. Ohshiro T, Calderhead RG. Low-level laser therapy: a practical introduction. Wiley, New York. 1988; 17: 28-34.

2. B Huang YY, Chen ACH, Carroll JD, Hamblin MR. Biphasic dose response in low-level light therapy. Dose Response. 2009; 7: 358-383. PMID: 20011653

3. Olten P, Young S, Dyson M. The direct effect of $860 \mathrm{~nm}$ light on cell proliferation and on succinic dehydrogenase activity of human fibroblasts in vitro. Laser Ther. 1995; 7: 55-60

4. Kushibiki T, Awazu K. Blue laser irradiation enhances extracellular calcification of primary mesenchymal stem cells. Photomed Laser Surg. 2009; 27: 493-8. PMID: 19405859

5. Hrnjak M, Kuljic-Kapulica N, Budisin A, Giser A. Stimulatory effect of low-power density $\mathrm{He}-\mathrm{Ne}$ laser radiation on human fibroblasts in vitro. Vojnosanit Pregl. 1995; 52: 539-46. PMID: 8644477

6. Boulton M, Marshall J. He-Ne laser stimulation of human fibroblast proliferation and attachment in vitro. Lasers Life Sci. 1986; 1: 125-34

7. Pogrel MA. Application of laser and cryosurgery in oral and maxillofacial surgery. Curr Opin Dentistry. 1991; 1: 263-270. PMID: 1801987

8. Gasparyan VC. Method of determination of aortic valve parameters for its reconstruction with autopericardium: an, experimental study. J Thorac Cardiovasc Surg. 2000; 119: 386387. PMID: 10649219

9. Rochkind S, Rousso M, Nissan M, Villarreal M, Barr-Nea L, Rees DG. Systemic effects of low-power laser irradiation on the peripheral and central nervous system, cutaneous wounds and bums. Lasers Surg Med. 1989; 9: 174-182. PMID: 2716462

10. Lizarelli RFZ, Lamano-Carvalho TL, Brentegani LG. Histometrical evaluation of the healing of the dental alveolus in rats after irradiation with a low-powered GaAlAs laser. SPIE. 1999; 3593: 49-55.

11. Tudy H, Maltz L, Oron U. Low-level laser irradiation (LLLI) promotes proliferation of mesenchymal and cardiac stem cells in culture, Laser Sung Med. 2007; 39: 373-378. PMID: 17457844.

12. Baharvand H, Ashtiani SK, Valojerdi MR, Shahverdi A, Taee A, Sabour D. Establishment and in vitro differentiation of a new embryonic stem cell line from human blastocyst. Differentiation. 2004; 72 (5): 224-9. PMID: 15270778

13. Gao X, Xing D. Molecular mechanisms of cell proliferation induced by low-power laser irradiation. J Biomed Sci. 2009; 16: 4. PMID: 19272168

14. Cohen N, Lubart R, Rubinstein S, Breitbart H. Light irradiation of mouse spermatozoa: stimulation of in vitro fertilization and calcium signals. Photochem Photobiol. 1998; 68: 407- 413. PMID: 9747596

15. Kokoska ER, Wolff AB, Smith GS, Miller TA. Epidermal growth factor-induced cytoprotection in human intestinal cells involves intracellular calcium signaling. J Surg Res. 2000; 88: 97 103. PMID: 10644473

16. Duan R, Liu TC, Li Y, Guo H, Yao LB. Ignal transduction pathways involved in low intensity $\mathrm{He}-\mathrm{Ne}$ laser-induced respiratory burst in bovine neutrophils: a potential mechanism of low intensity laser biostimulation. Lasers Surg Med. 2001; 29 (2): 174-8. PMID: 11553907

17. Vindrieux D, Escobar P, Lazennec G. Emerging roles of chemokines in prostate cancer Endocr Relat Cancer. 2009; 16 (3): 663-673. PMID: 19556286

18. Ransohoff RM. Chemokines and chemokine receptors: standing at the crossroads of immunobiology and neurobiology. Immunity. 2009; 31 (5): 711-21. PMID: 19836265

19. Bièche I, Chavey C, Andrieu C, Busson M, Vacher S, Le Corre $\mathrm{L}$, et al. CXC chemokines located in the $4 \mathrm{q} 21$ region are upregulated in breast cancer. Endocr Relat Cancer 2007; 14 (4): 1039-1052. PMID: 18045955

20. Rot A, Von Andrian UH. Chemokines in innate and adaptive host defense: basic chemokinese grammar for immune cells. Annu Rev Immunol. 2004; 22: 891-928. PMID: 15032599

21. Lazennec G, Richmond A. Chemokines and chemokine receptors: new insights into cancer-related inflammation. Trends Mol Med. 2010; 16 (3): 133-44. PMID: 20163989

22. Caruz A, Samsom M, Alonso JM, Alcami J, Baleux F, Virelizier JL, et al. Genomic organization and promoter characterization of human CXCR4 gene. FEBS Lett. 1998; 426 (2): 271-278. PMID: 9599023.

23. Wegner SA, Ehrenberg PK, ChangG,Dayhoff DE,Sleeker AL, 
Michael NL. Genomic organization and functional characterization of the chemokine receptor CXCR4, a major entry co-receptor for human immunodeficiency virus type 1. J Biol Chem. 1998; 273 (8): 4754-60. PMID: 9468539

24. Lazarini F, Casanova P, Tham TN, De Clercq E, ArenzanaSeisdedos F, Baleux F, et al. Differential signalling of the chemokine receptor CXCR4 by stromal cell-derived factor 1 and the HIV glycoprotein in rat neurons and astrocytes. Eur J Neurosci. 2000; 12 (1): 117-25. PMID: 10651866

25. Doitsidou M, Reichman-Fried M, Stebler J, Köprunner M, Dörries J, Meyer D, et al. Guidance of primordial germ cell migration by the chemokine SDF-1. Cell. 2002; 111 (5): 647-59. PMID: 12464177
26. Müller A, Homey B, Soto H, Ge N, Catron D, Buchanan ME, et al. Involvement of chemokine receptors in breast cancer metastasis. Nature. 2001; 410 (6824): 50-56. PMID: 11242036

27. Scotton CJ, Wilson JL, Milliken D, Stamp G, Balkwill FR. Epithelial cancer cell migration: A role for chemokine receptors? Cancer Res. 2001; 61 (13): 4961-4965. PMID: 11431324

28. Jung MJ, Rho JK, Kim YM, Jung JE, Jin YB, Ko YG, et al. Upregulation of CXCR4 is functionally crucial for maintenance of stemness in drug-resistant non-small cell lung cancer cells. Oncogene. 2013; 32 (2): 209-21. PMID: 22370645 